\title{
Trace Amine-Associated Receptor 1 Localization at the Apical Plasma Membrane Domain of Fisher Rat Thyroid Epithelial Cells Is Confined to Cilia
}

\author{
Joanna Szumska ${ }^{a} \quad$ Maria Qatato $^{a} \quad$ Maren Rehders $^{a}$ Dagmar Führer ${ }^{b}$ \\ Heike Biebermann ${ }^{c}$ David K. Grandy ${ }^{\mathrm{e}}$ Josef Köhrle ${ }^{d}$ Klaudia Brix ${ }^{a}$ \\ ${ }^{a}$ Department of Life Sciences and Chemistry, Jacobs University Bremen, Bremen, ${ }^{b}$ Department of Endocrinology \\ and Metabolism and Division of Laboratory Research, University of Duisburg-Essen, Essen, and \\ 'Institut für Experimentelle Pädiatrische Endokrinologie and ${ }^{d}$ Institut für Experimentelle Endokrinologie,

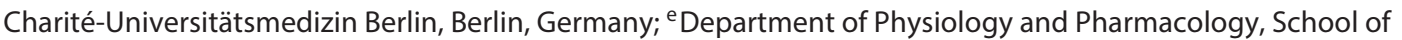 \\ Medicine and the Knight Cardiovascular Institute, Oregon Health \& Science University, Portland, Oreg., USA
}

\section{Key Words}

Thyroid gland · Thyroid hormones · Thyronamines · Taar1 ·

Thyroid follicle · G-protein-coupled receptors

\begin{abstract}
Background: The trace amine-associated receptor 1 (Taar1) is one member of the Taar family of G-protein-coupled receptors (GPCR) accepting various biogenic amines as ligands. It has been proposed that Taar 1 mediates rapid, membraneinitiated effects of thyronamines, the endogenous decarboxylated and deiodinated relatives of the classical thyroid hormones $T_{4}$ and $T_{3}$. Objectives: Although the physiological actions of thyronamines in general and 3-iodothyronamine $\left(T_{1} A M\right)$ in particular are incompletely understood, studies published to date suggest that synthetic $T_{1} A M$-activated Taar1 signaling antagonizes thyromimetic effects exerted by $T_{3}$. However, the location of Taar1 is currently unknown. Methods: To fill this gap in our knowledge we employed immunofluorescence microscopy and a polyclonal antibody to detect Taar1 protein expression in thyroid tissue from Fisher rats, wild-type and taar1-deficient mice, and in the polarized FRT cells. Results: With this approach we found that Taar1 is expressed in the membranes of subcellular compartments
\end{abstract}

of the secretory pathway and on the apical plasma membrane of FRT cells. Three-dimensional analyses further revealed Taar1 immunoreactivity in cilial extensions of postconfluent FRT cell cultures that had formed follicle-like structures. Conclusions: The results suggest Taar 1 transport along the secretory pathway and its accumulation in the primary cilium of thyrocytes. These findings are of significance considering the increasing interest in the role of cilia in harboring functional GPCR. We hypothesize that thyronamines can reach and activate Taar1 in thyroid follicular epithelia by acting from within the thyroid follicle lumen, their potential site of synthesis, as part of a nonclassical mechanism of thyroid autoregulation.

(c) 2015 European Thyroid Association Published by S. Karger AG, Basel

\section{Introduction}

Taar1 belongs to the family of G-protein-coupled receptors (GPCR) [1-5]. However, concerning its ligand interactions the receptor is promiscuous [6-10]. Taar1 is activated by biogenic amines such as $\beta$-phenylethylamine, $\beta$-tryptamine and $p$-tyramine, and modulates the action

\begin{tabular}{ll}
\hline KARGER 125/\% & $\begin{array}{l}\text { ( } 2015 \text { European Thyroid Association } \\
\text { Published by S. Karger AG, Basel } \\
2235-0640 / 15 / 0045-0030 \$ 39.50 / 0\end{array}$ \\
$\begin{array}{l}\text { E-Mail karger@karger.com } \\
\text { www.karger.com/etj }\end{array}$ &
\end{tabular}

Dr. Klaudia Brix

Department of Life Sciences and Chemistry Jacobs University Bremen

Campus Ring 1, DE-28759 Bremen (Germany)

E-Mail k.brix@jacobs-university.de 
of amphetamines $[5,7,11]$. In addition, a relative of the classical thyroid hormones (TH) $\mathrm{T}_{3}$ and $\mathrm{T}_{4}$, namely 3-iodothyronamine $\left(\mathrm{T}_{1} \mathrm{AM}\right)$, has been identified as a Taar 1 agonist in vitro $[7,10,12]$.

In contrast to a major interest in the action of thyronamines on peripheral $\mathrm{TH}$ target organs [for reviews see $10,13-15]$, the action of $\mathrm{T}_{1} \mathrm{AM}$ on the thyroid gland itself has received little attention. Likewise, the precise pattern of Taar1 tissue distribution and, in particular, where it is localized in thyroid epithelial cells, has not been studied in depth. Therefore, in this study we asked whether Taar 1 is expressed in the rodent thyroid gland.

Thyroid epithelial cells are the main cell type composing thyroid follicles, the functional units enabling the thyroid gland to fulfill its tasks of iodine organification and maintenance of constant TH levels in the blood circulation. Thyroid follicles are spherical structures in which polarized thyrocytes face the extracellular follicle lumen with their apical plasma membrane domain. The prohormone thyroglobulin is synthesized by thyrocytes and, upon secretion and iodination, is stored within the lumen. TSH binds to the basolateral TSH receptor - the beststudied thyroidal GPCR - thereby triggering the sequential proteolytic processing of thyroglobulin mediated by cysteine cathepsins that act in the pericellular space close to the apical cell surface, including cilia, and within endocytic compartments of thyroid epithelial cells, resulting in thyroglobulin utilization for TH liberation [16-19].

Here, we asked whether Taarl is expressed by thyrocytes in situ and FRT cells, a polarized nontransformed Fisher rat thyroid epithelial cell line [20,21], and, if so, where. FRT cells form tight monolayers and are characterized by apical and basolateral plasma membrane domains, making them well suited as an excellent thyroid epithelial cell model for trafficking studies [22-24].

Immunofluorescence microscopy revealed the presence of Taar1 immunoreactivity in the compartments of the secretory pathway of mouse and rat thyrocytes in situ and in vitro. Taarl immunoreactivity was additionally detected in a single prominent extension per FRT cell that was identified as the primary cilium by colocalization studies with acetylated $\alpha$-tubulin. The apical pole localization of Taar1 in FRT cell cilia was maintained during dome formation in long-term cultures. Hence, the results of this study provide novel insights into the role that Taar1-mediated signaling at cilia might play in promoting the function of thyroid epithelial cells. We propose that endogenous ligand(s), including $\mathrm{T}_{1} \mathrm{AM}$, are present in the thyroid follicle lumen, where they can trigger Taar 1 signaling in situ.

Taar1 in Cilia of FRT Cells

\section{Materials and Methods}

Animals, Thyroid Tissue Sampling and Cryosectioning

Male taar1-deficient mice or their C57BL6/J wild type (WT) littermates were kept in the animal facility of Jacobs University Bremen, Germany. The founder Taar $1^{-/}$mice were provided by Dr. D.K. Grandy and genotyped as previously described (www. komp.org/geneinfo.php?geneid=81264). BALB/c mice and Fisher rats were purchased from Charles River, Cologne, Germany. Mice and rats were housed under standard conditions, with a $12 / 12 \mathrm{~h}$ light/dark cycle and water and food ad libitum. Testing was conducted in accordance with institutional guidelines in the S1-laboratories of Jacobs University Bremen (SfAFGJS Az. 513-30-00/215-32 and 522-27-11/3-1, 05-A20 and A21).

Mice or rats were deeply anesthetized by $\mathrm{CO}_{2}$ inhalation or by using the inhalation anesthetic IsoFlou (Abbott $\mathrm{GmbH} \& \mathrm{Co} . \mathrm{KG}$, Wiesbaden-Delkenheim, Germany) before injection of $100 \mu \mathrm{l}$ of 10\% ketamine (CEVA Sante Animale, Düsseldorf, Germany) intraperitoneally. Perfusion was carried out through the heart with $0.9 \% \mathrm{NaCl}$, including $0.4 \mathrm{IU}$ heparin per milliliter. The head and neck regions were immediately separated and placed on ice for the entire dissection procedure.

The dissected thyroid glands were fixed in $4 \%$ PFA in $200 \mathrm{~mm}$ HEPES, pH 7.4, and left overnight at $4^{\circ} \mathrm{C}$, then cryopreservation was carried out by incubating in $0.5 \mathrm{M}$ and afterwards in $1 \mathrm{M} \mathrm{su}$ crose solution in phosphate-buffered saline (PBS), $\mathrm{pH} 7.4$, with each step another $24 \mathrm{~h}$ at $4^{\circ} \mathrm{C}$. Tissue samples were embedded in Jung tissue freezing medium (Leica Microsystems, Nussloch, Germany) and stored at $-20^{\circ} \mathrm{C}$ until sectioning on a cryostat (Leica CM1900, Leica Microsystems) into 5- $\mu$ m-thick sections and thawmounting on microscope slides.

\section{Cell Culture}

FRT cells [20] were grown at $37^{\circ} \mathrm{C}$ and $5 \% \mathrm{CO}_{2}$ in a moisturized atmosphere, in Coons F-12 medium (Sigma-Aldrich, Steinheim, Germany) containing $2.68 \mathrm{mg} / \mathrm{ml}$ sodium bicarbonate and 5\% fetal bovine serum (F7524, Sigma-Aldrich Chemie GmbH, Taufkirchen, Germany), supplemented with a hormone mixture consisting of $2 \mu \mathrm{g} / \mathrm{ml}$ insulin (I6634, Sigma-Aldrich), $20 \mathrm{ng} / \mathrm{ml}$ Gly-His-Lys complex (G7387, Sigma-Aldrich), $3.62 \mathrm{ng} / \mathrm{ml}$ hydrocortisone (H0135, Sigma-Aldrich), $5 \mu \mathrm{g} / \mathrm{ml}$ transferrin (11107-018, Invitrogen, Darmstadt, Germany), and $10 \mathrm{ng} / \mathrm{ml}$ somatostatin (S1763, Sigma-Aldrich).

\section{Indirect Immunofluorescence}

FRT cells were cultured on ethanol-sterilized coverslips in 6-well plates (Sarstedt, Nümbrecht, Germany). In some experiments, cells were incubated with $1 \mu \mathrm{M}$ LysoTracker Red DND-99 (L-7528, Molecular Probes, Leiden, The Netherlands) in culture medium for $45 \mathrm{~min}$ at $37^{\circ} \mathrm{C}$. Washing with culture medium twice for $3 \mathrm{~min}$ each was followed by a chase period of $30 \mathrm{~min}$ in complete cell culture medium and washes as described above before the cells were stained. The cells were fixed with $4 \%$ paraformaldehyde in $200 \mathrm{mM}$ HEPES, $\mathrm{pH}$ 7.4, for $20 \mathrm{~min}$ at room temperature followed by 3 times 5 -min incubation with calcium- and magnesiumfree PBS (CMF-PBS), i.e. $0.15 \mathrm{M} \mathrm{NaCl}, 2.7 \mathrm{mM} \mathrm{KCl}, 1.5 \mathrm{mM}$ $\mathrm{NaH}_{2} \mathrm{PO}_{4}, 8.1 \mathrm{mM} \mathrm{Na}_{2} \mathrm{HPO}_{4}$, pH 7.4. Permeabilization was performed with $0.1 \%$ saponin or $0.1 \%$ Triton X-100 in CMF-PBS for $5 \mathrm{~min}$ at room temperature. The residual embedding material of cryosections was washed out prior to the staining procedure by overnight incubation in PBS at $4^{\circ} \mathrm{C}$. 
For blocking, 3\% bovine serum albumin (BSA; Carl Roth $\mathrm{GmbH}$, Karlsruhe, Germany) in CMF-PBS was used for $1 \mathrm{~h}$ at $37^{\circ} \mathrm{C}$. The cells or sections were incubated with primary antibodies diluted in $0.1 \%$ BSA in CMF-PBS overnight at $4^{\circ} \mathrm{C}$. The sections and cells were labeled with rabbit anti-mouse Taar1, which was generated against a synthetic peptide from amino acid region 200245 of mouse Taar 1 conjugated to blue carrier protein (1:50; ABIN 351020, Antibodies Online, Aachen, Germany). Cells were colabelled with mouse anti-rat acetylated $\alpha$-tubulin (1:50; T7451, Sigma-Aldrich) antibodies, or treated with $10 \mu \mathrm{g} / \mathrm{ml}$ of biotin-conjugated Concanavalin A (ConA) from Canavalia ensiformis (C2272, Sigma-Aldrich) for $30 \mathrm{~min}$ at $4^{\circ} \mathrm{C}$. After washing with $0.1 \% \mathrm{BSA}$ in CMF-PBS, the cells or sections were incubated with Alexa 488or Alexa 546-conjugated secondary antibodies (1:200; A11070 and A11018, respectively; Molecular Probes, Karlsruhe, Germany) for $1 \mathrm{~h}$ at $37^{\circ} \mathrm{C}$ together with $5 \mu \mathrm{M}$ of the nuclear counterstain Draq5 $5^{\mathrm{TM}}$ (Biostatus Limited, Shepshed, UK). Specific antibodies were omitted in negative controls. Alternatively, lectin-stained cells were incubated with the Alexa Fluor ${ }^{\circledR}$ 546-conjugated streptavidin (S11225, Molecular Probes) as the secondary ConA detection label. After washing with CMF-PBS and deionized water, the sections and the cells on coverslips were mounted with embedding medium consisting of $33 \%$ glycerol, $14 \%$ Mowiol in $200 \mathrm{~mm}$ Tris- $\mathrm{HCl}, \mathrm{pH}$ 8.5 (Hoechst AG, Frankfurt, Germany).

Samples were analyzed with a confocal laser scanning microscope equipped with Argon and Helium-Neon lasers (LSM 510 Meta; Carl Zeiss Jena GmbH, Jena, Germany). Images were obtained at a pinhole setting of 1 Airy unit and at a resolution of $1,024 \times 1,024$ pixels. Micrographs were analyzed with the LSM 510 software, release 3.2 (Carl Zeiss Jena $\mathrm{GmbH}$ ). Staining and inspection of WT and taar1-deficient mouse thyroid tissue was performed under identical conditions on the same day to ensure maximal comparability of labeling.

\section{Immunoblotting}

Thyroid tissue from BALB/c and C57BL6/J mice as well as taar1-deficient mice on the C57BL6/J background was lysed in Triton-X 100 in PBS supplemented with a protease inhibitor cocktail, and protein determination was performed by the Neuhoff method using BSA as a standard [25]. Samples were loaded onto $12.5 \%$ SDS-polyacrylamide gels and semi-dry blotted onto nitrocellulose membranes, which were incubated with rabbit anti-mouse Taar1 antibodies (see above) at a dilution of 1:500 and horseradish peroxidase-conjugated secondary antibodies at a dilution of 1:5,000 before visualization by chemiluminescence onto XPosure film.

\section{Results}

\section{Taar1 Immunostaining in Mouse and Rat Thyroid}

Tissue

Immunofluorescence was observed in lumen-apposed apical plasma membrane domains (fig. 1, arrowheads) and in reticular and vesicular structures (fig. 1, arrows) present in the cytoplasm of cryosectioned thyroid follicle cells prepared from WT C57BL6/J mice and Fisher rat thyroid tissue using a polyclonal rabbit anti-mouse Taar 1 antiserum. In contrast, identically treated cryosections prepared from taar1-deficient mouse thyroid tissue exhibited weak to no immunoreactivity (fig. 1a), demonstrating the antiserum's specificity in immunofluorescence applications.

Immunoblotting revealed several bands in tissue lysates, including a band with an apparent molecular mass of approximately $38 \mathrm{kDa}$, as expected for Taarl, which was identified in thyroid tissue from $\mathrm{BALB} / \mathrm{c}$ and C57BL6/J mice, whereas this band was almost absent from taar $^{-/-}$mouse thyroid tissue (not shown).

\section{Taar1 Immunodetection by Differential \\ Permeabilization of FRT Cells}

We next investigated the subcellular localization and trafficking pathways of Taar 1 in FRT cells by immunofluorescence labeling and confocal laser scanning microscopy. As the polyclonal rabbit anti-Taar 1 antibodies were generated against an epitope in the third cytoplasmic loop of Taar1 (see above), we wanted to be sure the antibodies could penetrate the plasma membrane of FRT cells. Therefore, formaldehyde was used as a noncrosslinking fixative, and differential permeabilization experiments were conducted with saponin as a milder alternative to the stronger detergent Triton X-100 to promote the detection of intracellular structures more readily [26].

When confluent FRT cells were subjected to fixation without permeabilization, anti-Taar1 antibodies reacted with small punctate and disc-like structures that were detectable in a focal plane slightly above the monolayers (fig. 2a, $a^{\prime}$ ). Such structures were prominent and more broadly labeled when FRT cells were fixed and saponin permeabilized (fig. $2 b, b^{\prime}$ ). These results suggested the presence of Taar1 at appendages of the apical poles of FRT cells in monolayer cultures. When Triton X-100 was used as the detergent, many of the disc-like appendages were still immunolabeled, while additional structures with a reticular and vesicular appearance were detected as well (fig. 2c, $c^{\prime}$ ). The differential permeabilization of formaldehyde-fixed FRT cell monolayers therefore provided further evidence in support of Taar1 being an integral membrane protein at the apical pole of the thyroid epithelial cells.

\section{Taar1 Distribution in Compartments of the Secretory \\ Route}

Immunolabeling of confluent monolayer cultures of FRT cells following fixation and saponin permeabilization revealed distinct patterns of Taarl localization (fig. 3a, b), indicating heterogeneity of Taar1 distribution
Szumska/Qatato/Rehders/Führer/ Biebermann/Grandy/Köhrle/Brix 


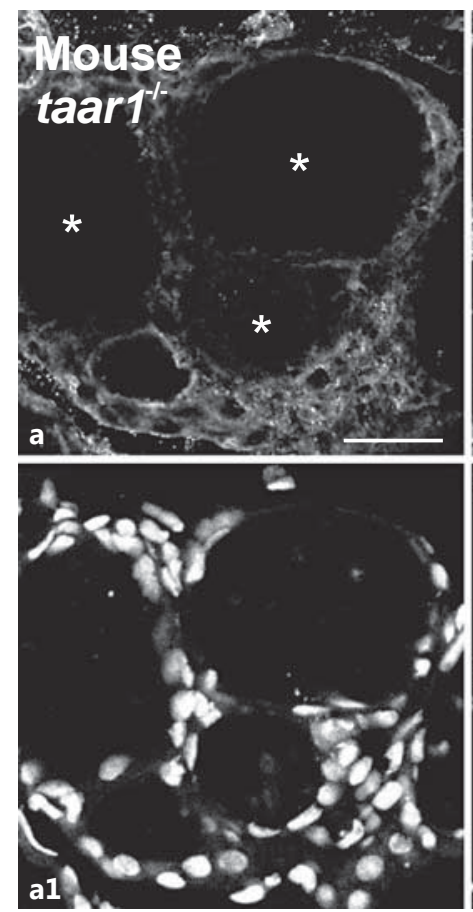

Fig. 1. Taar1 localization in mouse and rat thyroid tissue. Cryosections through thyroid tissue obtained from taar1 ${ }^{-/}$(a), WT C57BL/6 mice (b) and Fisher rats (c) were stained with rabbit antimouse Taar 1 polyclonal antibodies and analyzed by confocal laser scanning microscopy. Note the absence of distinct staining in
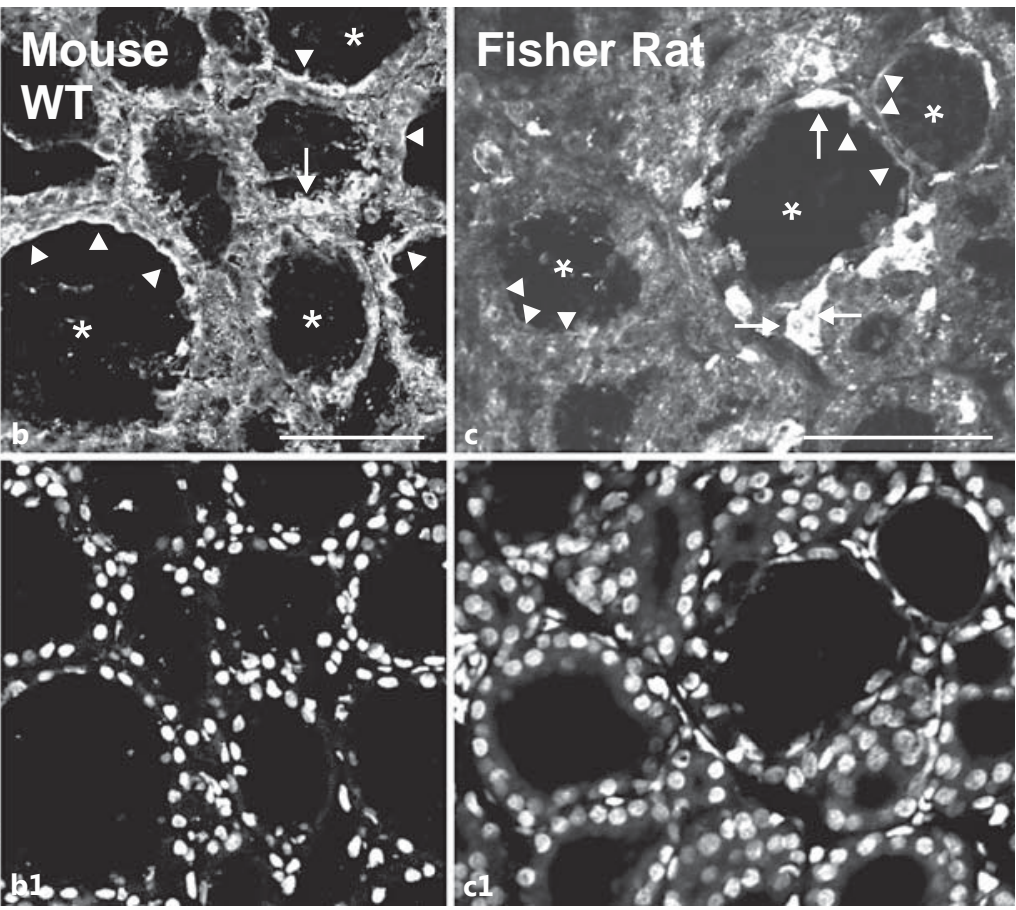

taar1-deficient mouse thyroid tissue (a) and the presence of Taar1-immunoreactive structures at the apical plasma membrane (arrowheads) and within follicle cells (arrows) in WT mouse and rat thyroid glands. Asterisks indicate the follicle lumen; nuclei were counterstained with Draq5 $5^{\mathrm{TM}}(\mathbf{a} 1-\mathbf{c 1})$. Scale bars $=100 \mu \mathrm{m}$. across the cell population. That is, all cells of the FRT monolayer exhibited Taar 1 immunoreactivity, but it was localized to different subcellular compartments under steady-state conditions. In particular, Taar 1 immunoreactivity was localized within the endoplasmic reticulum (ER; fig. 3c). Moreover, cisternal structures in the juxtanuclear region of FRT cells were immunoreactive for Taar1 (fig. 3d). Interestingly, Taar1-immunopositive vesicle-like structures were prominently observed to cluster at the borders of FRT cells in dense monolayer cultures (fig. 3e, arrows), suggesting that Taar1 protein is present in transport vesicles in transit to - or arriving at - the plasma membrane. Finally, the already described disclike structures (fig. 2), typically one per cell and focally above the microtubule-organizing center next to the nucleus, were detected by the anti-Taar1 antiserum (fig. 3a, $\mathrm{b}, \mathrm{f}, \mathrm{f}^{\prime}$, arrowheads). Viewed using confocal imaging, the stacks consisting of single focal planes, taken at a distance of $0.3 \mu \mathrm{m}$ and displayed in the $\mathrm{xz}$ direction as side views, revealed a prominent Taar1-containing cellular extension reminiscent of a cilium at the apical pole of the cells, with several shorter and thinner microvilli-like exten- sions occasionally observed as well (fig. $3 \mathrm{f}, \mathrm{f}^{\prime}$ ). Incubation with the fluid-phase marker LysoTracker Red DND-99 demonstrated anti-Taar1-positive structures were not present in compartments of the endocytic pathway (fig. 3f-f5).

\section{Taar1 Immunoreactivity Is Present in the Plasma Membrane of FRT Cell Cilia}

To confirm that Taarl is present in the plasma membrane of FRT cells, the anti-Taar1 polyclonal antiserum was used in combination with streptavidin to detect cell surface-bound biotinylated ConA. This lectin binds to a-mannopyranosyl and $\alpha$-glucopyranosyl residues of carbohydrate side-chains of membrane constituents and, consistent with the previous findings, Taar1-immunoreactivity (green) colocalized with ConA (red) in a structure that formed a cilia-like extension above the lectin-stained cell surface (fig. $4 a, a^{\prime}$ ). That these extensions were indeed primary cilia was confirmed based on the copresence of the well-established cilia marker acetylated $\alpha$-tubulin [27, 28] and Taar1 immunoreactivity (fig. 4b, b'). 

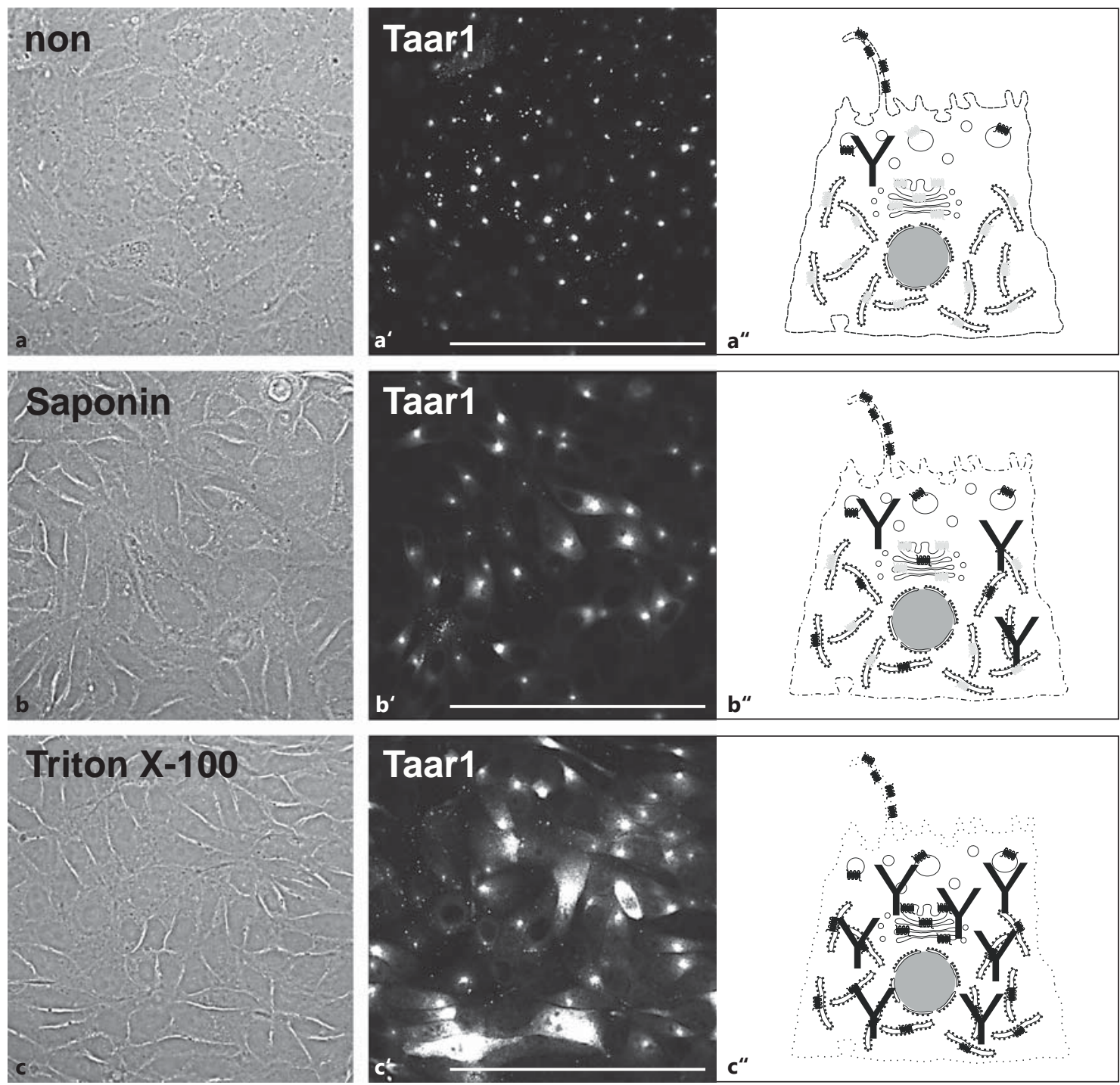

Fig. 2. Localization of Taar1 upon differential permeabilization of FRT cells. Confocal laser scanning micrographs of formaldehydefixed FRT cells before $\left(\mathbf{a}, \mathbf{a}^{\prime}\right)$ and after saponin $\left(\mathbf{b}, \mathbf{b}^{\prime}\right)$ or Triton X-100 (c, $\left.\mathbf{c}^{\prime}\right)$ permeabilization and immunolabeling with antibodies against Taar1, and corresponding schematic depictions (a"$\left.\mathbf{c}^{\prime \prime}\right)$ of increasing concentrations of antibodies recognizing Taar1 in intracellular compartments such as ER, Golgi apparatus and transport vesicles. Note Taar1 localization in small puncta and disc-like structures in non- and saponin-permeabilized cells (a', b'), while ER- and Golgi-localized Taar1 was detected in cells permeabilized with Triton X-100 ( $\left.\mathbf{c}^{\prime}\right)$. Corresponding phase-contrast $(\mathbf{a}-\mathbf{c})$ and single-channel fluorescence microscopic images are displayed $\left(\mathbf{a}^{\prime}-\mathbf{c}^{\prime}\right)$. Scale bars $=100 \mu \mathrm{m}$.
Taar1 Expression and Cilia Localization Is

Maintained upon Formation of Domes and

\section{Follicle-Like Structures}

In long-term cultures, FRT cells retain their morphological polarization with apical and basolateral plasma membrane domains because they express proteins involved in the formation of tight junctions. Furthermore, once confluence is reached, FRT cells can undergo addi- tional differentiation characterized by the formation of 'domes' observed in postconfluent, long-term cultures, which eventually convert into follicle-like structures (FLS) [29]. FLS resemble thyroid follicles in situ and thus provide an excellent in vitro model for studying protein trafficking with regard to the apical versus basolateral distribution of transmembrane proteins in thyrocytes in situ. 
Fig. 3. Heterogeneity of Taar1 distribution in FRT cells. Confocal laser scanning micrographs of formaldehyde-fixed and saponin-permeabilized FRT cells in confluent monolayers were immunolabeled with commercially prepared (Antibodies Online) polyclonal antibodies against Taar1 (a-f5, green signals) as well as incubated with LysoTracker Red DND-99 before fixation and immunostaining (f-f5, red signals). Immunostaining revealed the heterogeneity of the Taar1 distribution across the cell population $(\mathbf{a}, \mathbf{b})$. Note that Taar 1 was found in the compartments of the secretory pathway of FRT cells, namely the ER (c), the Golgi apparatus (d) and in vesicles that lined up along the borders of neighboring cells (e, arrows). Significantly, Taar1 immunoreactivity was absent from endocytic compartments (f-f5). Taar1 was additionally present in thin and broader extensions of the apical plasma membrane domains (arrowheads), indicative of its presence in cilia. Single-channel, overlays of different channels and corresponding phase-contrast micrographs are depicted as indicated. Nuclei were counterstained with Draq5 ${ }^{\mathrm{TM}}$ (blue signals). Scale bars $=20$ $\mu \mathrm{m}(\mathbf{a}-\mathbf{c}, \mathbf{e}), 10 \mu \mathrm{m}(\mathbf{d})$ and $50 \mu \mathrm{m}$ (f-f5). The images in panels $\mathbf{c}$ and $\mathbf{f}-\mathbf{f 5}$ are extended foci of single sections, with $0^{\circ}$-projections along $\mathrm{xz}$ depicted in $\mathbf{f}$ and $\mathbf{f}^{\prime}$, where the position of the cover glasses and schematic sketches of epithelial cells are given to assist with orientation.
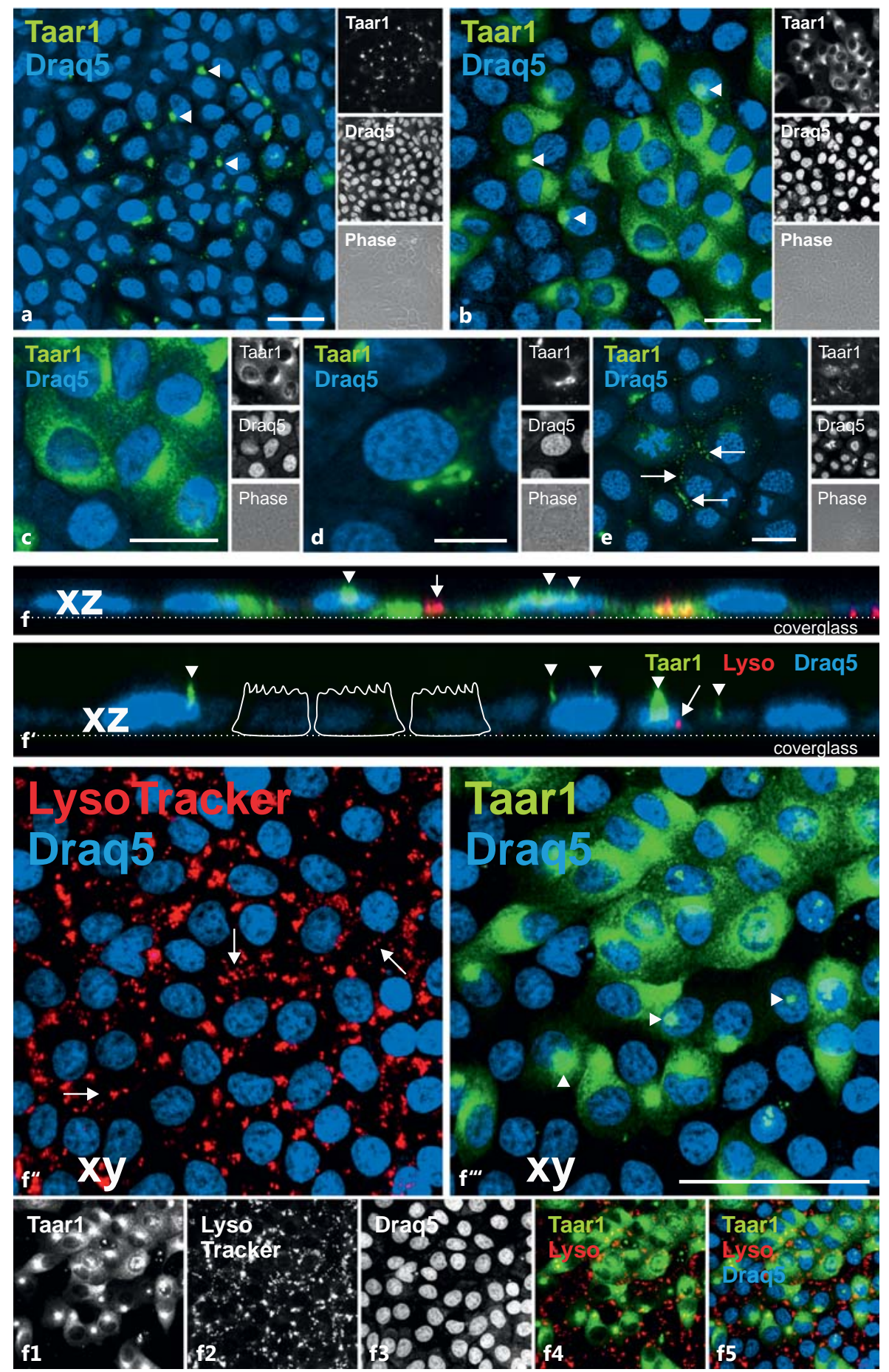

Consequently, we examined Taar1 localization in assembled FLS as a function of long-term FRT cell culture. In such cultures Taar 1 immunoreactivity was localized at the plasma membrane domain associated with the follicular lumen (fig. $5 a, b$, arrows), i.e. at the future apical plasma membrane domain of cells in the FLS. Thus, Taar1 trafficking was reversed while the monolayer lifted up for dome formation (for a schematic illustration, see fig. $5 \mathrm{a}^{\prime}$ ). However, the cells migrating underneath the domes kept their apical Taar1 localization in cilia pointing toward the future FLS lumen (fig. 5a, b). 

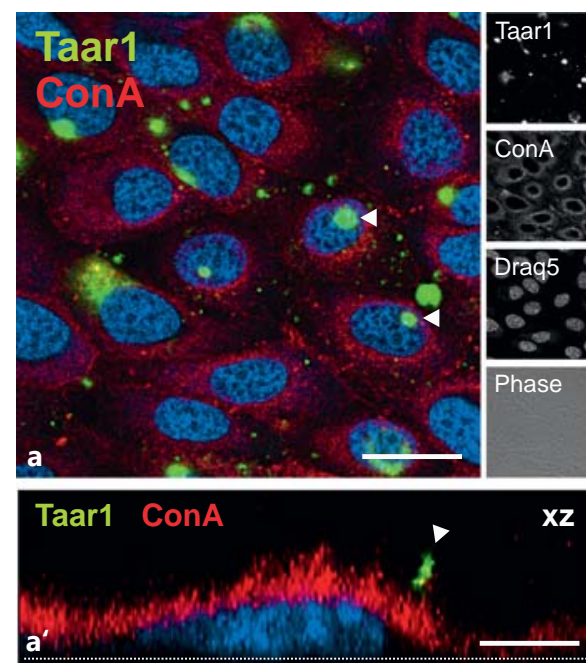
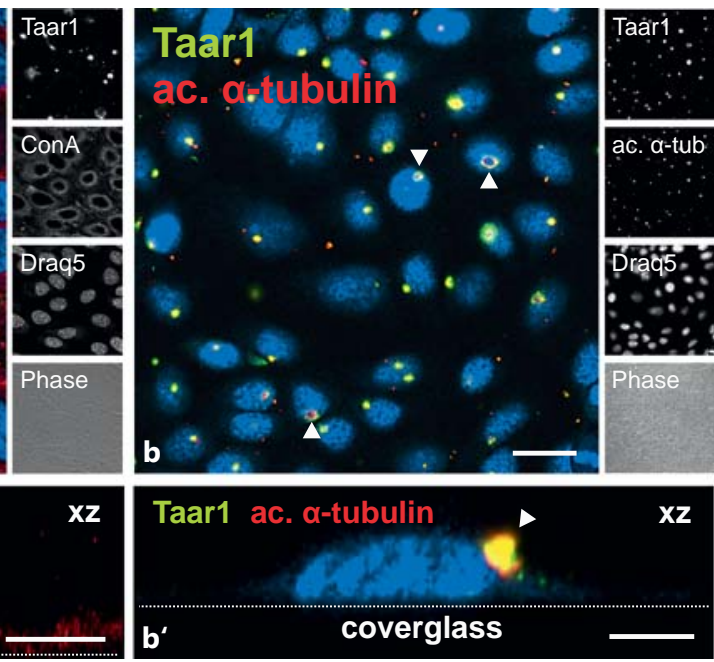

Fig. 4. Localization of Taarl at the surface of FRT cells. Confocal laser scanning micrographs of formaldehyde-fixed and saponinpermeabilized FRT cells in confluent monolayers were immunolabeled with commercially prepared polyclonal rabbit antibodies directed against Taar1 (green signals) and costained with the lectin ConA (a, a', red signals) or antibodies specific for acetylated a-tubulin (b, b', red signals). Lectin costaining of the glycocalyx revealed that Taar1 immunoreactivity is localized to plasma mem- brane appendages (arrowheads in $\mathbf{a}, \mathbf{a}^{\prime}$ ), while antiacetylated a-tubulin staining demonstrated the presence of Taar1 in cellular extensions identified as cilia (arrowheads in $\mathbf{b}, \mathbf{b}^{\prime}$ ). Single-channel overlays of different channels and corresponding phase-contrast micrographs are depicted as indicated. Nuclei were counterstained with Draq5 ${ }^{\mathrm{TM}}$ (blue signals). Scale bars $=20 \mu \mathrm{m}(\mathbf{a}, \mathbf{b})$ and $5 \mu \mathrm{m}\left(\mathbf{a}^{\prime}\right.$, $\left.\mathbf{b}^{\prime}\right)$. The images in $\mathbf{a}^{\prime}$ and $\mathbf{b}^{\prime}$ are $\mathrm{xz}$ projections in which the positions of the cover glass are given for orientation purposes.
Additionally, we observed that among individual cells of FLS, some were characterized by an enhanced expression of Taar1 (fig. 5a, c, d, arrowheads), which underscored the heterogeneous nature of Taarl expression in individual cells of long-term cultures of the Fisher rat thyroid epithelial FRT cells.

\section{Discussion}

Intriguingly, $\mathrm{T}_{1} \mathrm{AM}$ and $\mathrm{T}_{0} \mathrm{AM}$, the deiodinated and decarboxylated molecular relatives of classic $\mathrm{TH}$ [30], have been proposed to be the endogenous ligands of Taar1 [12], a conjecture supported by studies where synthetic thyronamines significantly influenced whole animal and cellular physiology [for reviews, see 7, 10, 13]. Despite these provocative findings, the contribution of Taar1 and $\mathrm{T}_{1} \mathrm{AM}$ to thyroid homeostasis is poorly understood. Consequently, to bridge this gap in our knowledge we designed and conducted the present study to determine: (1) whether Taarl is expressed in the thyroid glands of WT mice and rats; (2) whether Taar 1 is expressed in the rat thyroid epithelial cell line FRT, and (3) if Taar1 expression is detected, what is its subcellular localization?

\section{Taar1 in Primary Cilia at the Apical Surface of}

Polarized Thyroid Epithelial Cells

Data on the subcellular localization of Taar1 in potential target cells - including thyroid epithelial cells are rare due, in part, to it being an intrinsic, low-abundance, poorly immunogenic membrane protein. These obstacles were overcome in the present study by our use of immunofluorescence microscopy to compare Taar1 immunoreactivity present in taar1-deficient mice to immunoreactivity in thyroid tissue prepared from WT mice, Fisher rats and FRT cells. This approach allowed us to establish the specificity of the commercially generated (Antibodies Online) polyclonal rabbit anti-mouse Taar 1 antibody used, and revealed the intracellular distribution pattern of Taar 1 immunoreactivity in the secretory pathway of FRT cells. The most noteworthy observation was the colocalization of Taar1 immunostaining with the cilia marker acetylated $\alpha$-tubulin on the apically located primary cilium of FRT cells. Long-term cultures of FRT cells were also investigated in our study because this cell line is known to form 'domes' that actively pump ions, solute and water, and thus start to lift up from the bottom of the culture dish. They initially form half-spheres that can then transit into 'thyroid fol-
36

Eur Thyroid J 2015;4(suppl 1):30-41 DOI: $10.1159 / 000434717$
Szumska/Qatato/Rehders/Führer/ Biebermann/Grandy/Köhrle/Brix 
Fig. 5. Localization of Taar1 upon formation of domes and FLS. Confocal laser scanning micrographs of formaldehydefixed and saponin-permeabilized FRT cells in postconfluent cultures upon formation of domes and FLS were immunolabeled with rabbit polyclonal antibodies generated against Taar1 (green signals). Side views of single sections in a z-stack are projected along the $\mathrm{xz}$ direction (a), single sections taken at the bottom, median and top poles of a typical FLS are depicted in xy (b-d), and corresponding schematic drawings of FLS ( $\left.\mathbf{a}^{\prime}\right)$ with indications on where sections were positioned in $\mathbf{b}-\mathbf{d}\left(\mathbf{b}^{\prime}-\mathbf{d}^{\prime}\right)$ highlight the localization of Taar 1 at the apical plasma membrane domains pointing towards the inside of the forming, future FLS lumen. Note that few individual cells displayed significant expression of Taar1 (arrowheads). Single-channel and corresponding phase-contrast micrographs are depicted as indicated in the side panels. Nuclei were counterstained with Draq5 $5^{\mathrm{TM}}$ (blue signals). Scale bars $=10 \mu \mathrm{m}(\mathbf{a})$ and $20 \mu \mathrm{m}$ (b-d).
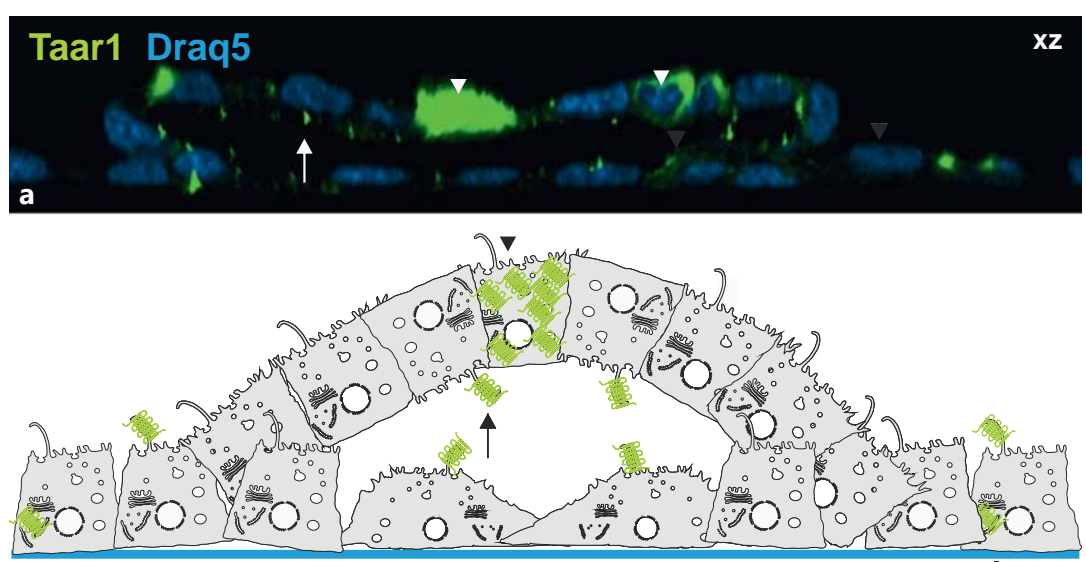

$\mathbf{a}^{\prime}$

coverglass

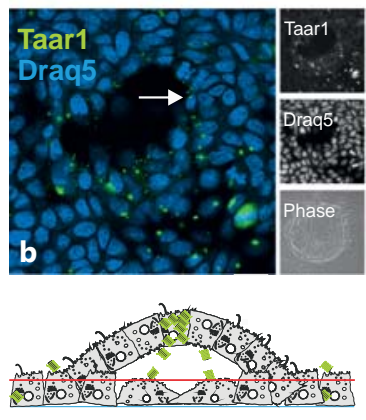

$\mathbf{b}^{\prime}$
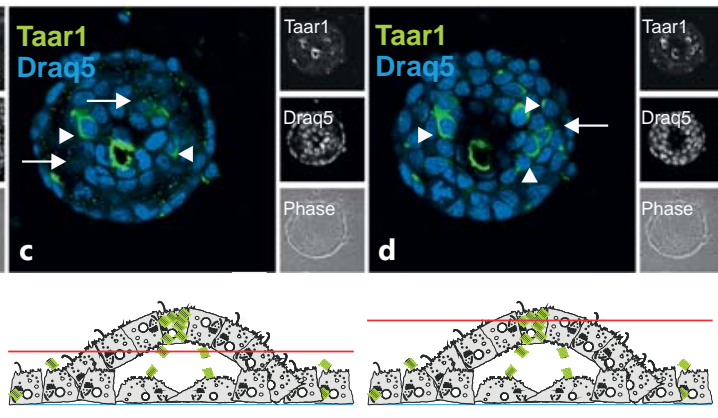

$\mathbf{c}^{\prime}$

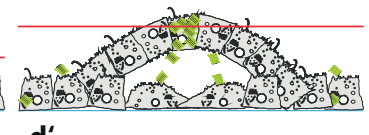

$\mathbf{d}^{\prime}$

\section{Taar1 Trafficking to Reach Primary Cilia of}

Thyrocytes

GPCRs are known to be expressed in small amounts [41]. Accordingly, it is assumed that only few ligand and receptor molecules are sufficient to mediate ligand-triggered signaling via G-proteins either at the plasma membrane or by intracellular signaling microdomains [42]. Hence, it was proposed that GPCR signaling depends on their assembly in specific subdomains of the plasma membrane, such as lipid raft-like microdomains or in cilia [43-45]. Indeed, the findings of our present study support the interpretation that the Taarl protein is targeted to and follows the secretory pathway to reach cilia at the apical plasma membrane domain of thyroid epithelial cells in situ and in vitro. The molecular determinants of Taar1 trafficking are presently unknown, but it is conceivable that targeting sequences exist similar to those functioning in other ciliary-located GPCRs [46]. Taar1 accumulates in easily detectable, antenna-like structures extending from polarized FRT cells into the extracellular milieu (see fig. 3-5). 


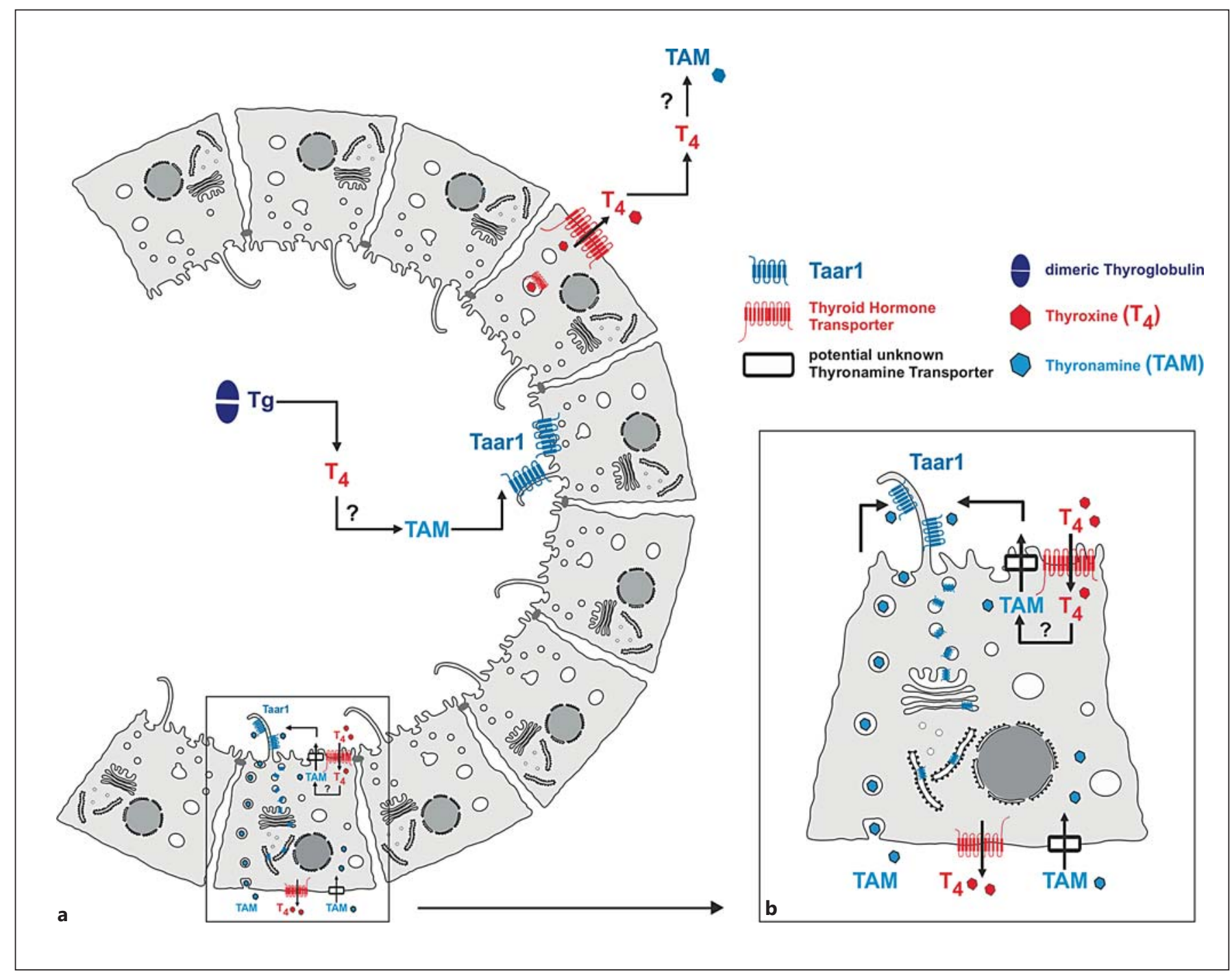

Fig. 6. Schematic representation of the putative location of thyronamine generation and contribution to autoregulation of the thyroid gland. Thyronamines can, in principle, be generated by extraor intrathyroidal means which involve deiodination and decarboxylation of iodothyronines generated by the degradation of thyroglobulin within the thyroid follicles (a). Thyroglobulin degradation is mediated by cysteine cathepsins $\mathrm{B}, \mathrm{K}, \mathrm{L}$, and/or $\mathrm{S}$, starting in the extracellular follicle lumen and continuing in the com- partments of the endocytic pathway $[17,19]$. If generated by extrathyroidal means, thyronamines need to be imported by unknown transporter molecules (black boxes). Since TH deiodination is catalyzed by integral membrane enzymes and decarboxylation for generation of thyronamines is a cytosolic process, thyronamine transporters must also be present at the endolysosomal and the plasma membranes of thyrocytes, if thyronamines are generated by intrathyroidal means (b).
The assembly of such antenna-resembling cilia depends on intraflagellar transport which is required for elongation of the axoneme and codetermines the protein composition of the cilial plasma membrane [45, 47]. In keeping with this notion, primary cilia are currently viewed as providing a privileged environment for signaling in which GPCRs assemble in a concentrated fashion. Moreover, small molecules and ions become enriched in cilia relative to the cytoplasm by several orders of magnitude, even though a diffusion barrier, for example by molecular fences, is absent [45].

It was recently described that Taars other than Taar1 are uniquely localized on cilia of specific olfactory neurons [48]. This neural cell type (with stem cell properties) bears a number of cellular appendages, thereby harboring multiple dendrite-like cilia per cell, which extend 
from the cell surface into air at the neuro-epithelium-air interface in the nasal cavity. In clear contrast, it is important to note that Taar 1 is present in the primary cilium of thyroid epithelial cells, as detected in this study. Primary cilia are formed by many cell types; typically only one copy is present per cell, which is also the case for thyrocytes $[31,44,49,50]$. To our knowledge, no reports have been presented on GPCRs localized to the apical plasma membrane domain of thyroid epithelial cells.

We determine that the ciliated apical plasma membrane domain of thyroid epithelial cells bears critical functions in that it harbors the means for formation of iodothyronines during $\mathrm{TH}$ generation while also serving as a platform of initial cysteine cathepsin-mediated thyroglobulin processing for TH liberation [16-19]. Hence, the localization of Taar1 in the primary cilium at the apical plasma membrane domain of thyroid epithelial cells in vitro and in situ provides the source for novel hypotheses in thyroid cell biology. Moreover, the presence of Taar1 in a hair-like extension reaching out into the juxtamembrane thyroglobulin-filled thyroid follicle lumen, where the precursors $(\mathrm{TH})$ of its ligands (thyronamines) are liberated, implies a possible involvement of Taar 1 in thyroid autoregulation. We hypothesize that Taar1 may serve an important sensory function to detect changes in the molecular composition of the thyroid follicle lumen. However, the suggested hypotheses will have to be sustained by further experiments.

Likewise, physiologically relevant intrathyroidal ligands of Taar1 need to be identified in the future. Besides $3-\mathrm{T}_{1} \mathrm{AM}$, another interesting candidate - also known as an activating Taar1 ligand - is tyramine [51], which was previously proposed to be involved in the generation of $\mathrm{H}_{2} \mathrm{O}_{2}$ at the apical pole of thyrocytes [52, 53]. However, an answer to the open question as to which of the biogenic amines that are known to trigger Taarl in vitro may be important in situ for thyroid regulation depends on the availability of methods to qualitatively and quantitatively determine the amounts of intrathyroidal biogenic amines.

\section{Thyronamines and Taarl in Thyroid Autoregulation}

Arguably, the central question in the $\mathrm{T}_{1} \mathrm{AM}$ field has to do with its physiological role(s) in healthy and diseased states. This fundamental question remains unanswered, in part, due to the fact that the molecular mechanisms of thyronamine (e.g. $\mathrm{T}_{1} \mathrm{AM}$ ) generation are not known. Although the location of $\mathrm{T}_{1} \mathrm{AM} / \mathrm{T}_{0} \mathrm{AM}$ production is thought to occur in extrathyroidal tissue in $\mathrm{T}_{4}$-substitut- ed (athyreotic) humans [54], this interpretation is still controversial, especially for rodents. Furthermore, although it has been isolated from tissue [12, 14], the enzymes responsible for $\mathrm{T}_{1} \mathrm{AM}$ generation remain elusive [55]. While deiodination of TH has been studied intensely, including those in the thyroid gland itself [56], only a few investigations have attempted to identify the thyronamine-generating decarboxylating enzyme [57] and its tissue location, which remains enigmatic. It is known, however, that ${ }^{125}$ I-labeled $\mathrm{T}_{1} \mathrm{AM}$ added exogenously through injection into the blood circulation of BALB/C mice results in the accumulation of ${ }^{125}$ I-radioactivity in the thyroid gland, where it persists with a long half-life and can be competed with excess nonradioactive $T_{1} A M$, suggesting specificity of thyroidal uptake [58]. These findings suggest that $\mathrm{T}_{1} \mathrm{AM}$ or metabolites derived therefrom may act as a potentially important ligand of intrathyroidal Taar1 in situ.

In this context, our observation of Taar1 in subcellular compartments associated with the secretory pathway, in addition to cilia at the apical pole of the structurally polarized thyroid epithelial cells, raises interesting possibilities with regard to possible $\mathrm{T}_{1} \mathrm{AM}$-triggered, Taar1-mediated physiological responses of the thyroid gland (see fig. 6). One exciting corollary is that thyronamines (e.g. $\mathrm{T}_{1} \mathrm{AM}$ ) are generated within the thyroid gland, as are classical $\mathrm{TH}$. Therefore, based on our present findings, we here propose a scenario wherein the thyronamines trigger responses of thyrocytes in the thyroid gland via stimulation of apically located Taarl. As schematically sketched in figure $6, \mathrm{~T}_{1} \mathrm{AM}$ could be generated within the thyroid follicle lumen to be in reach of the apically located Taar 1 receptors. This scenario would explain how $\mathrm{T}_{1} \mathrm{AM}$ could act as an agonist of Taarl expressed on the apical poles of thyroid epithelial cells.

In summary, the results of this study provide novel hypotheses for a potential role of Taar1-mediated signaling in thyroid autoregulation by demonstrating the presence of Taar 1 on the primary cilium at the apical pole of thyroid epithelial cells. In the future it will be important to determine whether or not $\mathrm{T}_{1} \mathrm{AM}$ or $\mathrm{T}_{0} \mathrm{AM}$, or other thyroid-relevant biogenic amines, are able to trigger Taar 1 actions in FRT cells. In this context it will also be informative to determine whether an iodothyronine decarboxylating activity is present in rat thyroid epithelial cells. Studies of this kind should eventually help to establish whether and to what extent $\mathrm{T}_{1} \mathrm{AM}$-Taar1 interactions contribute to the autoregulation of the thyroid gland in health and disease. 


\section{Acknowledgements}

The authors would like to thank Ms. Vaishnavi Venugopalan and Ms. Nadja Oellrich for their contributions to the initial phase of this project. This work was supported by the Deutsche Forschungsgemeinschaft, DFG, grant BR 1308/11-1 to K.B., BI 893/51 to H.B., FU 356/7-1 to D.F., and KO 922/17-1 to J.K. in the framework of the priority program SPP 1629 'Thyroid Trans Act'.

\section{Disclosure Statement}

The authors declare that no conflict of interest exists.

\section{References}

$>1$ Borowsky B, Adham N, Jones KA, Raddatz R, $>10$ Zucchi R, Accorroni A, Chiellini G: Update Artymyshyn R, Ogozalek KL, Durkin MM, Lakhlani PP, Bonini JA, Pathirana S, Boyle N, $\mathrm{Pu}$ X, Kouranova E, Lichtblau H, Ochoa FY, Branchek TA, Gerald C: Trace amines: identification of a family of mammalian $\mathrm{G}$ protein-coupled receptors. Proc Natl Acad Sci USA 2001;98:8966-8971.

-2 Bunzow JR, Sonders MS, Arttamangkul S, Harrison LM, Zhang G, Quigley DI, Darland T, Suchland KL, Pasumamula S, Kennedy JL, Olson SB, Magenis RE, Amara SG, Grandy DK: Amphetamine, 3,4-methylenedioxymethamphetamine, lysergic acid diethylamide, and metabolites of the catecholamine neurotransmitters are agonists of a rat trace amine receptor. Mol Pharmacol 2001;60: 1181-1188.

3 Lindemann L, Ebeling M, Kratochwil NA, Bunzow JR, Grandy DK, Hoener MC: Trace amine-associated receptors form structurally and functionally distinct subfamilies of novel $\mathrm{G}$ protein-coupled receptors. Genomics 2005; 85:372-385.

$>4$ Lindemann L, Meyer CA, Jeanneau K, Bradaia A, Ozmen L, Bluethmann H, Bettler B, Wettstein JG, Borroni E, Moreau JL, Hoener MC: Trace amine-associated receptor 1 modulates dopaminergic activity. J Pharmacol Exp Ther 2008;324:948-956.

5 Grandy DK: Trace amine-associated receptor 1 - family archetype or iconoclast? Pharmacol Ther 2007;116:355-390.

6 Hart ME, Suchland KL, Miyakawa M, Bunzow JR, Grandy DK, Scanlan TS: Trace amineassociated receptor agonists: synthesis and evaluation of thyronamines and related analogues. J Med Chem 2006;49:1101-1112.

7 Zucchi R, Chiellini G, Scanlan TS, Grandy DK: Trace amine-associated receptors and their ligands. Br J Pharmacol 2006;149:967978.

-8 Tan ES, Groban ES, Jacobson MP, Scanlan TS: Toward deciphering the code to aminergic G protein-coupled receptor drug design. Chem Biol 2008;15:343-353.

>9 Kleinau G, Pratzka J, Nürnberg D, Grüters A, Führer-Sakel D, Krude H, Köhrle J, Schöneberg T, Biebermann H: Differential modulation of $\beta$-adrenergic receptor signaling by trace amine-associated receptor 1 agonists. PLoS One 2011;6:e27073. on 3-iodothyronamine and its neurological and metabolic actions. Front Physiol 2014;5: 402.

11 Reese EA, Bunzow JR, Arttamangkul S, Sonders MS, Grandy DK: Trace amine-associated receptor 1 displays species-dependent stereoselectivity for isomers of methamphetamine, amphetamine, and para-hydroxyamphetamine. J Pharmacol Exp Ther 2007;321: 178-186.

12 Scanlan TS, Suchland KL, Hart ME, Chiellini G, Huang Y, Kruzich PJ, Frascarelli S, Crossley DA, Bunzow JR, Ronca-Testoni S, Lin ET, Hatton D, Zucchi R, Grandy DK: 3-Iodothyronamine is an endogenous and rapid-acting derivative of thyroid hormone. Nat Med 2004; 10:638-642.

13 Scanlan TS: Minireview: 3-Iodothyronamine $\left(\mathrm{T}_{1} \mathrm{AM}\right)$ : a new player on the thyroid endocrine team? Endocrinology 2009;150:11081111.

14 Piehl S, Hoefig CS, Scanlan TS, Kohrle J: Thyronamines - past, present, and future. Endocr Rev 2011;32:64-80.

15 Grandy DK: TAAR1 transforms thinking about a plant alkaloid that transformed the practice of medicine. Int J Neuropsychopharmacol 2014;17:1545-1547.

16 Brix K, Lemansky P, Herzog V: Evidence for extracellularly acting cathepsins mediating thyroid hormone liberation in thyroid epithelial cells. Endocrinology 1996;137:1963-1974.

17 Friedrichs B, Tepel C, Reinheckel T, Deussing J, von Figura K, Herzog V, Peters C, Saftig P, Brix K: Thyroid functions of mouse cathepsins B, K, and L. J Clin Invest 2003;111:17331745 .

18 Jordans S, Jenko-Kokalj S, Kühl NM, Tedelind S, Sendt W, Brömme D, Turk D, Brix K: Monitoring compartment-specific substrate cleavage by cathepsins B, K, L, and S at physiological $\mathrm{pH}$ and redox conditions. BMC Biochem 2009;10:23.

19 Dauth S, Arampatzidou M, Rehders M, Yu DMT, Führer D, Brix K: Thyroid cathepsin K - roles in physiology and thyroid disease. Clin Rev Bone Miner Metab 2011;9:94-106.

20 Ambesi-Impiombato FS, Parks LA, Coon HG: Culture of hormone-dependent functional epithelial cells from rat thyroids. Proc Natl Acad Sci USA 1980;77:3455-3459.
21 Nitsch L, Tramontano D, Ambesi-Impiombato FS, Quarto N, Bonatti S: Morphological and functional polarity of an epithelial thyroid cell line. Eur J Cell Biol 1985;38:57-66.

22 Linke M, Herzog V, Brix K: Trafficking of lysosomal cathepsin B-green fluorescent protein to the surface of thyroid epithelial cells involves the endosomal/lysosomal compartment. J Cell Sci 2002a;115:4877-4889.

23 Linke M, Jordans S, Mach L, Herzog V, Brix K: Thyroid stimulating hormone upregulates secretion of cathepsin B from thyroid epithelial cells. Biol Chem 2002b;383:773-784.

24 Brix K, Dunkhorst A, Mayer K, Jordans S: Cysteine cathepsins: cellular roadmap to different functions. Biochimie 2008;90:194-207.

-25 Neuhoff V, Philipp K, Zimmer HG, Mesecke $\mathrm{S}$ : A simple, versatile, sensitive and volumeindependent method for quantitative protein determination which is independent of other external influences. Hoppe Seylers Z Physiol Chem 1979;360:1657-1670.

26 Arampatzidou M, Rehders M, Dauth S, Yu DM, Tedelind S, Brix K: Imaging of protease functions - current guide to spotting cysteine cathepsins in classical and novel scenes of action in mammalian epithelial cells and tissues. Ital J Anat Embryol 2011;116:1-19.

27 Piperno G, LeDizet M, Chang XJ: Microtubules containing acetylated $\alpha$-tubulin in mammalian cells in culture. J Cell Biol 1987; 104:289-302.

28 Hammond JW, Cai D, Verhey KJ: Tubulin modifications and their cellular functions. Curr Opin Cell Biol 2008;20:71-76.

29 Tonoli H, Flachon V, Audebet C, Callé A, Jarry-Guichard T, Statuto $\mathrm{M}$, Rousset B, Munari-Silem Y: Formation of three-dimensional thyroid follicle-like structures by polarized FRT cells made communication competent by transfection and stable expression of the connexin-32 gene. Endocrinology 2000;141: 1403-1413.

30 Piehl S, Heberer T, Balizs G, Scanlan TS, Kohrle J: Development of a validated liquid chromatography/tandem mass spectrometry method for the distinction of thyronine and thyronamine constitutional isomers and for the identification of new deiodinase substrates. Rapid Commun Mass Spectrom 2008; 22:3286-3296. 
-31 Graebert KS, Bauch H, Neumüller W, Brix K, Herzog V: Epithelial folding in vitro: studies on the cellular mechanism underlying evagination of thyrocyte monolayers. Exp Cell Res 1997;231:214-225.

-32 Bernier-Valentin F, Trouttet-Masson S, Rabilloud R, Selmi-Ruby S, Rousset B: Threedimensional organization of thyroid cells into follicle structures is a pivotal factor in the control of sodium/iodide symporter expression. Endocrinology 2006; 147:2035-2042.

- 33 Bravo SB, Garcia-Rendueles ME, Garcia-Rendueles AR, Rodrigues JS, Perez-Romero S, Garcia-Lavandeira M, Suarez-Fariña M, Barreiro F, Czarnocka B, Senra A, Lareu MV, Rodriguez-Garcia J, Cameselle-Teijeiro J, Alvarez CV: Humanized medium $(\mathrm{h} 7 \mathrm{H})$ allows long-term primary follicular thyroid cultures from human normal thyroid, benign neoplasm, and cancer. J Clin Endocrinol Metab 2013;98:2431-2441.

- 34 Studer H, Peter HJ, Gerber H: Natural heterogeneity of thyroid cells: the basis for understanding thyroid function and nodular goiter growth. Endocr Rev 1989;10:125-135.

- 35 Aeschimann S, Gerber H, von Grünigen C, Oestreicher M, Studer H: The degree of inhibition of thyroid follicular cell proliferation by iodide is a highly individual characteristic of each cell and differs profoundly in vitro and in vivo. Eur J Endocrinol 1994;130:595-600.

-36 Roger PP, Baptist M, Dumont JE: A mechanism generating heterogeneity in thyroid epithelial cells: suppression of the thyrotropin/ cAMP-dependent mitogenic pathway after cell division induced by cAMP-independent factors. J Cell Biol 1992;117:383-393.

- 37 Derwahl M, Studer H: Hyperplasia versus adenoma in endocrine tissues: are they different? Trends Endocrinol Metab 2002;13:2328.

38 Davies TF, Latif R, Minsky NC, Ma R: The emerging cell biology of thyroid stem cells. J Clin Endocrinol Metab 2011;96:2692-2702.

39 De Felice M, Di Lauro R: Minireview: intrinsic and extrinsic factors in thyroid gland development: an update. Endocrinology 2011; 152:2948-2956.
40 Fierabracci A: Identifying thyroid stem/progenitor cells: advances and limitations. J Endocrinol 2012;213:1-13.

41 Maguire JJ, Parker WAE, Foord SM, Bonner TI, Neubig RR, Davenport AP: International Union of Pharmacology. LXXII. Recommendations for trace amine receptor nomenclature. Pharmacol Rev 2009;61:1-8.

42 Calebiro D, Godbole A, Lyga S, Lohse MJ: Trafficking and function of GPCRs in the endosomal compartment. Methods Mol Biol 2015;1234:197-211.

43 Eggenschwiler JT, Anderson KV: Cilia and developmental signaling. Annu Rev Cell Dev Biol 2007;23:345-373.

44 Rupik W: Ultrastructural studies of cilia formation during thyroid gland differentiation in grass snake embryos. Micron 2013;44:228-237.

45 Nachury MV: How do cilia organize signaling cascades? Phil Trans R Soc B 2014;369: 20130465.

46 Berbari NF, Johnson AD, Lewis JS, Askwith CC, Mykytyn K: Identification of ciliary localization sequences within the third intracellular loop of $\mathrm{G}$ protein-coupled receptors. Mol Biol Cell 2008a; 19:1540-1547.

47 Sun C-H, Leroux MR: The roles of evolutionarily conserved functional modules in ciliarelated trafficking. Nat Cell Biol 2013;15: 1387-1397.

-48 Johnson MA, Tsai L, Roy DS, Valenzuela DH, Mosley C, Magklara A, Lomvardas S, Liberles SD, Barnea G: Neurons expressing trace amine-associated receptors project to discrete glomeruli and constitute an olfactory subsystem. Proc Natl Acad Sci USA 2012;109: 13410-13415.

49 Martin A, Hedinger C, Häberlin-Jakob M, Walt H: Structure and motility of primary cilia in the follicular epithelium of the human thyroid. Virchows Arch B Cell Pathol Incl Mol Pathol 1988;55:159-166.

50 Basten SG, Giles RH: Functional aspects of primary cilia in signaling, cell cycle and tumorigenesis. Cilia 2013;2:6.
51 Tan ES, Naylor JC, Groban ES, Bunzow JR, Jacobson MP, Grandy DK, Scanlan TS: The molecular basis of species-specific ligand activation of trace amine-associated receptor 1 (TAAR 1 ). ACS Chem Biol 2009;4:209-220.

52 Masini-Repiso AM, Cabanillas AM, Andrada MC, Coleoni AH: Monoamine oxidase A mediates iodotyrosine formation induced by monoamines in bovine thyroid particulate fraction. Horm Metab Res 1990;22:80-84.

53 Kraiem Z, Sadeh O, Youdim MB: Monoamine oxidase activity and triiodothyronine biosynthesis in human cultured thyroid cells. Br J Pharmacol 1989;96:465-469.

54 Hoefig CS, Kohrle J, Brabant G, Dixit K, Yap B, Strasburger CJ, Wu Z: Evidence for extrathyroidal formation of 3-iodothyronamine in humans as provided by a novel monoclonal antibody-based chemiluminescent serum immunoassay. J Clin Endocrinol Metab 2011;96: 1864-1872.

55 Hackenmueller SA, Marchini M, Saba A, Zucchi R, Scanlan TS: Biosynthesis of 3-iodothyronamine $\left(T_{1} A M\right)$ is dependent on the sodium-iodide symporter and thyroperoxidase but does not involve extrathyroidal metabolism of $\mathrm{T}_{4}$. Endocrinology 2012;153:56595667.

56 Köhrle J: Thyrotropin (TSH) action on thyroid hormone deiodination and secretion: one aspect of thyrotropin regulation of thyroid cell biology. Horm Metab Res Suppl 1990;23:18-28.

57 Hoefig CS, Renko K, Piehl S, Scanlan TS, Bertoldi M, Opladen T, Hoffmann GF, Klein J, Blankenstein O, Schweizer U, Köhrle J: Does the aromatic L-amino acid decarboxylase contribute to thyronamine biosynthesis? Mol Cell Endocrinol 2012;349:195-201.

-58 Chiellini G, Erba P, Carnicelli V, Manfredi C, Frascarelli S, Ghelardoni S, Mariani G, Zucchi R: Distribution of exogenous $\left[{ }^{125} \mathrm{I}\right]-3$-iodothyronamine in mouse in vivo: relationship with trace amine-associated receptors. J Endocrinol 2012;213:223-230. 